\title{
EFFECT OF FEEDING REGIMES ON REPRODUCTIVE PERFORMANCE OF NILE TILAPIA (Oreochromis niloticus) BROODFISH IN A COMMERCIAL HATCHERY
}

\author{
Ramadan M. Abou-Zied \\ Anim. Prod. Dept. Faculty of Agriculture, Fayoum University, Egypt.
}

\begin{abstract}
:
The present work was conducted in commercial hatchery at Shakshouk, Fayoum Governorate. The trial started at 6/5/2005 and lasted for 122 days.

A number of 105 females and 35 males of one year old broodfish weighing 170 to $175 \mathrm{~g}$ in average were used per hapa. Five feeding regimes were used $(0.5,1.0,1.5,2.0$ and $3.0 \%$ of broodfish body mass/day) forming 5 treatments (regimes). Seeds were collected at 10 day intervals starting from 28/5/2005. Data obtained were on reproductive performance, growth performance and economic evaluation.

Data revealed that the $1 \%$ feeding rate showed better reproductive performance and economic evaluation. The $0.5 \%$ feeding rate tended to show slightly lower values. The other higher levels of feeding were not recommended.
\end{abstract}

Key words: Nile tilapia, broodfish, feeding rate, productive

performance fecundity and economics.

\section{INTRODUCTION:}

Nile tilapia (Oreochromis niloticus) has rapidly became an important species for aquaculture although their intensive culture remains constrained by poor spawning synchrony and low fecundity adding significant cost to hatchery production (Campos-Mendoza et al., 2004). In traditional systems tilapia broodfish are reared in ponds with or without supplementary feed and fry are collected from the edges of ponds. Recently, spawning of broodfish in large nylon hapas suspended in ponds has been developed (Little et al., 1995, 1997 and Bhujel et al., 1998) and became commercialized and proven to be economically viable (Little et al., 1997 and Bhujel, 1997).

In tilapia quantity and quality of food can affect its frequency of spawning (Hughes and Behrends, 1983; Guerrero and Guerrero, 1985; Macintosh and Little, 1995) and the number of seed per clutch (Guerrero and Guerrero, 1985; Rana, 1986, 1988; Macintosh and Little, 1995). Moreover, Izquierdo et al. (2001) sited that broodstock nutrition is one of the most important factors limiting fish fry production and larval quality. Gunasekera et al. (1997) pointed out to the critical role of nutrition to brooding females, in supplying the essential nutrients required for gonadal development as well as the performance of their seeds and larvae. Macintosh and Little (1995) fed brooding females at a rate of $1.5 \%$ of the total fish biomass/day, but Beveridge and McAndrew (2000) used a feeding rate of 1 $\%$ of body weight/day.

As the feeding rate is one of the constraints in commercial hatcheries at Fayoum Governorate, the present work was conducted aiming to study the effect of feeding regime on performance of Nile tilapia broodfish. A simple economic evaluation was conducted.

Fayoum J. Agric. Res. \& Dev., Vol. 20, No. 2, July, 2006 


\section{MATERIALS AND METHODS}

The present work was conducted in commercial hatchery at Shakshouk, El-Fayoum Governorate. The trial was started at 6/5/2005 and lasted for 122 days.

Five feeding regimes were used $(0.5,1.0,1.5,2.0$ and $3.0 \%$ of broodfish body mass/day) forming five treatments (regimes).

One year old Nile tilapia (Oreochromis niloticus) belonging to the year 2004 generation with an average weight of $172 \mathrm{~g} \pm 2.0$ were stocked for spawning into ten hapas (each of $7 \mathrm{~m}$ length $\times 4 \mathrm{~m}$ width $\times 1.2 \mathrm{~m}$ height), two per each treatment. The distance between each treatment to another $1 \mathrm{~m}$. Hapas were fixed in an earthen pond (one feddan area $\times 1 \mathrm{~m}$ depth) where $1 / 3$ of the water level was exchanged with fresh water every 3 days. Fish were stocked at a density of 140 fish (sex ratio is 3 females / one male) per hapa. Fish were fed the commercial diets containing $25.34 \%$ crude protein (CP) and $4.450 \mathrm{kcal} \mathrm{GE} / \mathrm{g}$ at a rate of five regimes once daily as used in commercial hatcheries at Fayoum Governorate. The diet was a product of Zocontrol factory, 6 October city, sinking feed of $3 \mathrm{~mm}$ diameter. Fish body mass was determined at 4 week intervals and feeding rates were adjusted accordingly.

Production of seed (eggs \& recent spawned fry) and rate of spawning were compared with the feeding regimes.

Seeds were collected at 10 day intervals from 28/5/2005. Early in the morning, females carrying the seeds were taken from the hapa and returned after taking out the seeds. Seeds were taken to hatchery laboratory, then washed by potassium permengenate solution to prevent bacterial and fungal infection. All seeds were weighed, seed samples were taken, weighed and counted, then seeds were placed for hatching in 15 litter plastic jars, where a gentle and continuous flow of water was maintained. Broodfish were weighed at the end of the trial.

Data obtained were spawned females number/hapa, \% spawned females, seed weight/hapa, seed number/hapa, seed weight/female, absolute fecundity (Rana, 1988), relative fecundity (RF) (Campos-Mendoza et al., 2004), number of spawning/female/period, female average weight/period, broodstock weight at the start and at the end, average daily gain, \% SGR, feed intake (FI) and feed conversion ratio (FCR) and a simple economic evaluation.

Statistical analysis were performed using SPSS, 1997. Statistical significant between treatments was evaluated at the 5\% probability level. The completely random design and linear regression analysis were used.

\section{RESULTS:}

Water quality:

Averages of water temperature, dissolved oxygen (DO) and water $\mathrm{pH}$ during the experimental period are presented in Table 1.

Such data $\left(30 \pm 0.5{ }^{\circ} \mathrm{C}, 6.2 \pm 0.1 \mathrm{mg} / \mathrm{l} \mathrm{DO}\right.$ and $8.1 \pm 0.1 \mathrm{pH}$ in average) were in the ranges reported by Mironova (1977); Popma and Lovshin (1996); Ambali (1990); Watanabe et al. (1992); Bevis (1994); Siddiqui et al. (1997); Siddiqui et al. (1998) and Ali (2001).

Fayoum J. Agric. Res. \& Dev., Vol. 20, No. 2, July, 2006 
EFFECT OF FEEDING REGIMES ON REPRODUCTIVE

Table (1). Water quality parameters during the experimental period.

\begin{tabular}{|l|ccc|}
\hline Item & Min. & Max. & Average \pm SE \\
\hline Temperature, C. & 29 & 33 & $30.55 \pm 0.48$ \\
Dissolved oxygen, mg/l. & 5.8 & 6.5 & $6.17 \pm 0.08$ \\
pH & 7.8 & 8.2 & $\mathbf{8 . 0 6} \pm 0.05$ \\
\hline
\end{tabular}

Broodstock reproductive performance:

Reproductive performance parameters of Nile tilapia (Oreochromis niloticus) broodstock as affected by feeding regime is shown in Table 2 .

Significant differences $(\mathrm{P} \leq 0.05)$ were found in reproductive performance of broodfish due to the tested feeding regimes. In general the lowest two feeding regimes $(0.5 \& 1.0 \%$ of live body weight $)$ resulted in better reproductive performance than the other higher feeding regimes $(1.5$, 2.0 and $3.0 \%$ of live body weight) with Nile tilapia broodstock. Comparing the lowest two feeding regimes $(0.5 \& 1.0 \%$ of live body weight), both of them showed insignificant differences in seed weight and seed number/hapa/collection as well as in relative fecundity. However, the broodfish fed at a rate of $1.0 \%$ of their body weight had higher $(\mathrm{P} \leq 0.05)$ number of spawning/female/period.

Table (2). Reproductive performance per collection of Nile tilapia broodstock as affected by feeding regime.

\begin{tabular}{|c|c|c|c|c|c|c|}
\hline \multirow{2}{*}{ Parameters } & \multicolumn{5}{|c|}{ Feeding regime, $\%$ of live body mass } & \multirow{2}{*}{ SED* } \\
\hline & 0.5 & 1.0 & 1.5 & 2.0 & 3.0 & \\
\hline Spawned females number per collection & $13.15^{\mathrm{b}}$ & $17.85^{\mathrm{a}}$ & $10.85^{\mathrm{bc}}$ & $9.30^{\mathrm{bc}}$ & $7.70^{\mathrm{c}}$ & 2.13 \\
\hline Spawned females $\%^{(1)}$ & $12.52^{\mathrm{b}}$ & $17.00^{\mathrm{a}}$ & $10.33^{\mathrm{bc}}$ & $8.86^{\mathrm{bc}}$ & $7.33^{c}$ & 2.03 \\
\hline Seeds weight/hapa, g & $1088.0^{\mathrm{a}}$ & $1117.5^{\mathrm{a}}$ & $722.5^{\mathrm{b}}$ & $605.0^{\mathrm{b}}$ & $535.0^{\mathrm{b}}$ & 157.29 \\
\hline Average seed No/hapa ${ }^{(2)}$ & $12424.7^{\mathrm{a}}$ & $13095.5^{\mathrm{a}}$ & $8035.5^{\mathrm{b}}$ & $6310.3^{\mathrm{b}}$ & $5596^{\mathrm{b}}$ & 1755 \\
\hline Average seeds weight/ fen & $8.32^{\mathrm{a}}$ & $6.16^{\mathrm{b}}$ & $6.52^{\mathrm{b}}$ & $6.46^{\mathrm{b}}$ & $6.73^{\mathrm{b}}$ & 0.54 \\
\hline Seed No/ female (absolute fecundity) ${ }^{(3)}$ & $940.7^{\mathrm{a}}$ & $740.3^{\mathrm{b}}$ & $714.9^{\mathrm{b}}$ & $675.6^{\mathrm{b}}$ & $705.4^{\mathrm{b}}$ & 60.27 \\
\hline Relative fecundity ${ }^{(4)}$ & $5.31^{\mathrm{a}}$ & $4.00^{\mathrm{a}}$ & $3.45^{\mathrm{b}}$ & $3.15^{\mathrm{b}}$ & $3.08^{\mathrm{b}}$ & 0.31 \\
\hline No of spawning/ fem & $1.25^{\mathrm{b}}$ & $1.70^{\mathrm{a}}$ & $1.03^{\mathrm{c}}$ & $0.89^{\mathrm{d}}$ & $0.73^{\mathrm{e}}$ & 0.01 \\
\hline Female average weight, g. & 176.75 & 185.3 & 212.35 & 220.40 & 233.9 & 9.76 \\
\hline
\end{tabular}

- Average in the same row having different superscripts differ significantly $\mathrm{P} \leq 0.05$.

* SED is the standard error of difference

(1) $=$ Spawned females number/hapa $\times 100 /$ No of female per hapa.

(2) $=$ Seed weight per hapa, $\mathrm{g} \times$ Seed No per gm

(3) $=(2) /$ Spawned females number per hapa

(4) $=(3) /$ Female average weight per period

$(5)=$ Spawned females number per hapa $\times$ No of collection/ Female No per hapa

Broodstock growth performance and feed utilization:

Table 3 presents growth performance and feed utilization of Nile tilapia broodstock as affected by feeding regime.

It was observed that as a level of feeding increased as Nile tilapia final weight and gain increased. However, such increases were not great specially when looking to specific growth rate (SGR\%). Feed conversion values showed gradual improvement as the level of feeding increased.

Fayoum J. Agric. Res. \& Dev., Vol. 20, No. 2, July, 2006 
Table (3). Growth performance and feed utilization efficiency of Nile tilapia broodstock as affected by feeding regime.

\begin{tabular}{|c|c|c|c|c|c|c|}
\hline \multirow{2}{*}{ Items } & \multicolumn{5}{|c|}{ Feeding regime, $\%$ of live body mass } & \multirow{2}{*}{$\mathrm{SED}^{*}$} \\
\hline & 0.5 & 1.0 & 1.5 & 2.0 & 3.0 & \\
\hline Average initial weight/fish, $g$ & 172.5 & 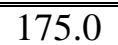 & 172.5 & $\overline{170.0}$ & 170.0 & 8.06 \\
\hline$h t / f i c$ & 180.0 & 192.5 & 257.5 & 275.0 & 317.5 & 8.22 \\
\hline Total gain, $g^{(1)}$ & 7.5 & 17.5 & 85.0 & 105.0 & 147.5 & 9.35 \\
\hline Average daily gain/fish, g ${ }^{(2)}$ & 0.06 & 0.14 & 0.70 & 0.86 & 1.21 & 0.077 \\
\hline SGR, \% ${ }^{(3)}$ & 0.034 & 0.077 & 0.328 & 0.395 & 0.512 & 0.037 \\
\hline Total 1 & 96.6 & 196 & 289.8 & 380.8 & 571.2 & \\
\hline $\begin{array}{l}\text { Total feed used, kg/hapa } \\
\text { FCR: }\end{array}$ & 13.524 & 27.440 & 40.572 & 53.312 & 79.968 & 1602 \\
\hline Excluding seed weight ${ }^{(4)}$ & $14.52^{\mathrm{a}}$ & $11.69^{\mathrm{ab}}$ & $4.81^{\mathrm{b}}$ & $4.20^{\mathrm{b}}$ & $3.86^{\mathrm{b}}$ & 3.09 \\
\hline Excluding fish weight ${ }^{(5)}$ & $13.06^{\mathrm{d}}$ & $25.21^{\mathrm{d}}$ & $63.42^{\mathrm{c}}$ & $102.63^{\mathrm{b}}$ & $184.53^{\mathrm{a}}$ & 8.15 \\
\hline $\begin{array}{l}\text { Including fish weight and } \\
\text { seed weight }^{(6)}\end{array}$ & $7.95^{\mathrm{a}}$ & $6.85^{\mathrm{ab}}$ & $4.69^{\mathrm{bc}}$ & $4.03^{\mathrm{bc}}$ & $3.63^{\mathrm{c}}$ & 1.22 \\
\hline
\end{tabular}

- Average in the same row having different superscripts differ significantly $\mathrm{P} \leq 0.05$.

* SED is the standard error of difference.

(1) Final weight - Initial weight

(2) (1) /period in days.

(3) Specific growth rate $=100$ (ln Final weight $-\ln$ Initial weight) / period in days, where $\ln$ is the natural log.

(4) Total feed offered per hapa/ (1).

(5) Total feed offered per hapa/ Seed weight per hapa.

(6) Total feed offered per hapa/ (Total gain per hapa + Seed weight per hapa).

Table 4 shows the regression analysis between relative fecundity and broodstock body weight or feed intake.

Significant negative relationship was found between relative fecundity (RF) and broodstock body weight. Also, a negative relationship was found between RF and broodstock feed intake. This means that the increase in body weight due to the increase in feed intake reduced the relative fecundity of broodstock.

Table (4). Regression analysis between relative fecundity, RF (ŶY) and either broodstock body weight, wt or feed intake, FI.

\begin{tabular}{|c|ccc|}
\hline Item & $\hat{\mathbf{y}}=\mathbf{a}+\mathbf{b} \mathbf{x}$ & $\mathbf{r}$ & $\mathbf{n}$ \\
\hline $\mathrm{wt}$ & $\mathrm{RF}=7.24-0.019 \mathrm{wt}$ & $-0.537^{* *}$ & 20 \\
$\mathrm{FI}$ & $\mathrm{RF}=4.931-0.00023 \mathrm{FI}$ & $-0.564^{* *}$ & 20 \\
\hline
\end{tabular}

In other words increasing feeding rate results in undesired fattening for broodfish females. Such fattening reduce broodfish relative fecundity.

Economic evaluation of the tested feeding regimes: regimes.

Table 5 illustrates the economic evaluation of the tested feeding

The lowest two feeding regimes were more economic than the other higher feeding regimes $(0.5 \& 1.0 \%$ vs $1.5,2.0$ and $3.0 \%$ of body weight).

Fayoum J. Agric. Res. \& Dev., Vol. 20, No. 2, July, 2006 
Comparing the lowest feeding regimes, the $1.0 \%$ one tended to show better net returns $(5.7 \%)$ than the $0.5 \%$ one. This is due to higher seed number/ hapa/period.

Discussion:

Nutrition is one of the factors that can limit fish fry production (Izquierdo et al., 2001). Gunasekera et al. (1997) indicated that good nutrition supply the females by essential nutrients required for gonadal development as well as the performance of their seeds and larvae. Macintosh and Little (1995) fed their brooding females at a rate of $1.5 \%$ of the total fish biomass/day. Therefore, in the present study feeding rates of $0.5,1.0,1.5,2.0$ and $3.0 \%$ of broodfish live body weight/day were tested to evaluate broodfish reproductive performance and its economics.

Table (5). Economic evaluation of the tested feeding regime.

\begin{tabular}{|c|c|c|c|c|c|}
\hline \multirow{2}{*}{ Item } & \multicolumn{5}{|c|}{ Diet \% of body weight } \\
\hline & 0.5 & 1.0 & 1.5 & 2.0 & 3.0 \\
\hline Feed offered, kg & 13.52 & 27.44 & 40.57 & 53.31 & 79.97 \\
\hline Broodfish mass at the start, $\mathrm{kg}$. & 24.2 & 24.5 & 24.2 & 23.8 & 23.8 \\
\hline Broodfish mass at the end, kg. & 25.2 & 26.95 & 36.05 & 38.5 & 44.45 \\
\hline Seed No/hapa/period & 124247 & 130955 & 80355 & 63103 & 55960 \\
\hline Predicted fry No. ${ }^{(1)}$ & 86973 & 91669 & 56249 & 44172 & 39172 \\
\hline Feed cost, $L . E^{(2)}$ & 26.37 & 53.51 & 79.12 & 103.96 & 155.94 \\
\hline Other costs, L.E & 656.25 & 656.25 & 656.25 & 656.25 & 656.25 \\
\hline Total costs, L.E ${ }^{(3)}$ & 682.62 & 709.76 & 735.37 & 760.21 & 812.19 \\
\hline Broodfish selling, L.E ${ }^{(4)}$ & 226.8 & 242.55 & 360.5 & 385 & 444.50 \\
\hline Predicted fry selling, L.E & 4348.645 & 4583.425 & 2812.425 & 2208.605 & 1958.6 \\
\hline Total selling price, L.E & 4575.445 & 4825.975 & 3172.925 & 2593.605 & 2403.10 \\
\hline Net return, L.E & $3,892.82$ & $4,116.22$ & $2,437.56$ & $1,833.40$ & $1,590.91$ \\
\hline Net return, relative & 100 & 105.74 & 59.22 & 75.21 & 86.77 \\
\hline Total selling/Total costs & 6.70 & 6.80 & 4.31 & 3.41 & 2.96 \\
\hline $\begin{array}{l}\text { Total selling/Total costs, } \\
\text { relative, } \%\end{array}$ & 100 & 101.44 & 63.46 & 79.07 & 86.73 \\
\hline
\end{tabular}

(1) As $70 \%$ of the produced seeds were hatched (average of that found in commercial hatcheries, personal communication).

(2) Feed price 1950 L.E / ton

(3) The hatchery contains 80 hapa (total costs of hapa without feed $=656.25$ L.E)

(4) Brood selling price 9 and 10 L.E for (160-200 g) and (250-500 g) respectively

In the present study the reproductive performance was with the two lowest feeding rates ( 0.5 and $1.0 \%$ of live body weight/day) compared to the higher feeding rates tested (Table 2). The economic evaluation followed similar trend (Table 5) with better net returns with the feeding level of $1.0 \%$ of body weight. The regression analysis reflected the effect of the negative effect between relative fecundity and the feed consumed and consequently broodfish weight (Table 4). The low fecundity of broodstock of Nile tilapia was reported by Rana (1988), Baroiller and Jalabert (1989), Macintosh and Little (1995), Coward and Bromage (1998), Bhujel (2000) and Little and Hulata (2000). In the present study broodfish of Nile tilapia that reared in net enclosures had lower fecundity or relative fecundity than that reported

Fayoum J. Agric. Res. \& Dev., Vol. 20, No. 2, July, 2006 
by Camps-Mendoza et al. (2004) and Lu and Takeuchi (2004). Such trend could be illustrated through different factors.

Hughes and Behrends (1983) found a stocking density of $5 \mathrm{fish} / \mathrm{m}^{2}$ was more productive as compared to $10 \mathrm{fish} / \mathrm{m}^{2}$ in hapas and tanks. Such trend was followed in the present study showing the sutable stocking density in the hatchery. Popma and Lovshin (1996) mentioned an increase in seed production when the rearing temperature is above $25^{\circ} \mathrm{C}$ up to $30^{\circ} \mathrm{C}$. In the present study the temperature ranged between 29 and 33 with average value of $30.55 \mathrm{C}$ (Table 1).

Conclusion:

Under the study conditions, a feeding rate of $1.0 \%$ of broodfish body weight is preferable followed by $0.5 \%$ one.

\section{REFERENCES}

Ali, A.A.A. (2001). The effect of some nutritional treatments on fecundity, sex reversal and productive performance of Nile tilapia. Ph.D. Thesis, Fac. Agric., El-Fayoum, Cairo Univ., ARE.

Ambali, A.J.D. (1990). Effect of hapa size on conditioning of broodstock, (Oreochromis niloticus) in fertilized earthen ponds. M.Sc. Thesis. Asian Institute of Technology $101 \mathrm{pp}$.

Baroiller, J.F. and Jalabert B. (1989). Contribution of research in reproductive physiology to the culture of tilapias. Aquatic Living Resource 2: 105-116.

Beveridge, M.C.M. and McAndrew B.J. (2000). Tilapias: Biology and Exploitation. Kluwer, Dordrecht, The Netherlands, 505 pp.

Bevis, R. (1994). The effect of artificial nests on reproductive performance in the Nile tilapia (Oreochromis niloticus, L.) spawned in net hapas. M. Sc. Thesis, Asian Institute of Technology $111 \mathrm{pp}$.

Bhujel, R.C. (1997). A new record! Tilapia fry sale reached nearly 10 million a month. AASP Newsl. $24,16$.

Bhujel, R.C. (2000). A review of strategies for the management of Nile tilapia (Oreochromis niloticus) broodfish in seed production system, especially hapa based systems. Aquaculture, 181: 37-59.

Bhujel, R.C.; Little D.C. and Turner W.A. (1998). Quality monitoring of sex-reversed tilapia fry. Fish Farmer. pp. 34-37, (September/ October).

Campos-Mendoza, A.; McAndrew B.J.; Coward K. and Bromage N. (2004). Reproductive response of Nile tilapia (Oreochromis niloticus) to photoperiodic manipulation; effects on spawning periodicity, fecundity and egg size. Aquaculture, 231: 299-314.

Coward, K. and Bromage N.R. (1998). Histological classification of oocyte growth and the dynamics of ovarian recrudescence in Tilapia zillii. J. of fish biology, 53: 285-302.

Guerrero III, R.D. and Guerrero L.A. (1985). Effect of breeder size on fry production of Nile tilapia in concrete pools. Trans. Natl. Acad. Sci. Technol., Repub. Philipp. 7: 63-66.

Gunasekera, R.M.; Shim K.F. and Lam T.J. (1995). Effect of dietary protein level on puberty, oocyte growth and egg chemical composition in the tilapia, Oreochromis niloticus (L.). Aquaculture 134: 169-183.

Fayoum J. Agric. Res. \& Dev., Vol. 20, No. 2, July, 2006 
Gunasekera, R.M.; Shim K.F. and Lam T.J. (1997). Influence of dietary protein content on the distribution of amino acids in oocytes, serum and muscle of Nile tilapia, Oreochromis niloticus (L.). Aquaculture, 152: 205-221.

Hughes, D.G. and Behrends L.L. (1983). Mass production of Tilapia nilotica seed in suspended net enclosures. In: Fishelson, L., Yaron, Z. Eds., Proceedings of the International Symposium on Tilapia in Aquaculture. Tel. Aviv Univ., Tel Aviv, Israel, pp. 394-401 comps. .

Izquierdo M.S.; Fernandez-Palacios H. and Tacon A.G.J. (2001). Effect of broodstock nutrition on reproductive performance of fish. Aquaculture 197: 25-42.

Little, D.C. and Hulata G. (2000). Strategies for tilapia seed production. Handbook of Tilapias: Biology and Exploitation, pp 267-326.

Little, D.C.; Lin C.K. and Turner W.A. (1995). Commercial scale tilapia fry production in Thailand. World Aquaculture, 26: 20-24.

Little, D.C.; Macintosh D.J. and Edwards P. (1993). Improving spawning synchrony in the Nile tilapia, Oreochromis niloticus L. . Aquacult. Fish. Manage, 24: 399-405.

Little, D.C.; Turner W.A. and Bhujel R.C. (1997). Commercialization of a hatchery process to produce MT-treated Nile tilapia in Thailand. pp. 108-118. In: Alston, D.E. Green, B.W., Clifford, H.C. (Ms.), IV Symp., Aquaculture in Central America: Focusing on shrimp and tilapia, 22-24 April, Tegucigalpa, Honduras, Asociacion Nacional de Acuicultores de Honduras and the Latin American Chapter of the World Aquaculture Society, $237 \mathrm{pp}$.

Lu, J. and Takeuchi T. (2004). Spawning and egg quality of the tilapia Oreochromis niloticus fed solely on raw Spirulina throughout three generations. Aquaculture 234: 625-640.

Macintosh, D.J. and Little D.C. (1995). Nile tilapia Oreochromis niloticus . In: Bromage, N.R., Roberts, R.J. Eds. , Broodstock Management and Egg and Larval Quality. Blackwell, Cambridge, UK, 424 pp.

Mironova, N.V. (1977). Energy expenditure on egg production in young Tilapia mossambica and the influence of maintenance conditions on their reproductive intensity. J. lchthyol. 17: 627-633.

Popma, T.J. and Lovshin L.L. (1996). Worldwide prospects for commercial production of tilapia. Research and development No. 41, Dept., Fish., \& Allied Aquacult., Auburn Univ., AL, USA, 23 pp.

Rana, K.J. (1986). Parental influences on egg quality, fry production and fry performance in Oreochromis niloticus Linnaeus and O. mossambicus Peters. PhD Thesis, Institute of Aquaculture, Univ. of Stirling, UK, p. 295.

Rana, K.J. (1988). Reproductive biology and the hatchery rearing of tilapia eggs and fry. In: Muir, J.F., Roberts, J.F., Roberts, R.J. Eds., Recent Advances in Aquaculture, vol. 3. Croom Helm, London and Sydney and Timber Press, Portland, OR, USA, pp. 343-406.

Siddiqui, A.Q.; Al-Hafedh Y.S. and Ali S.A. (1998). Effect of dietary protein level on the reproductive performance of Nile tilapia, Oreochromis niloticus L. Aquaculture Res. 29: 349-358.

Fayoum J. Agric. Res. \& Dev., Vol. 20, No. 2, July, 2006 
Siddiqui, A.Q.; Al-Harbi A.H. and Al-Hafedh Y.S. (1997). Effects of food supply on size at first maturity, fecundity and growth of hybrid tilapia (Oreochromis niloticus $\times$ O. aureus) in outdoor concrete tanks in Saudi Arabia. Aquaculture Res. 28: 341-349.

SPSS (1997). Statistical Package for Social Sciences, for windows. Release 8.0. SPSS Inc., Chicago, USA.

Watanabe, W.O.; Smith S.T.; Wicklund R.I. and Ola B.L. (1992). Hatchery production of Florida red tilapia seed in brakishwater tanks under natural mouthbrooding and clutch removal methods. Aquaculture, 102: 77-88.

تأثير نظم التظذية على الأداء التناسلى لأمهات البلطى النيلى فى مفرخ تجارى

$$
\begin{aligned}
& \text { رمضان محمد أبوزيد } \\
& \text { قسم الإنتاج الحيوانى- كلية الزراعة- جامعة الفيوم- مصر. }
\end{aligned}
$$

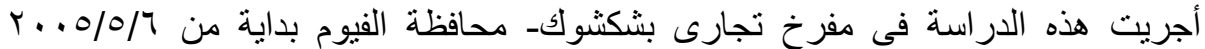

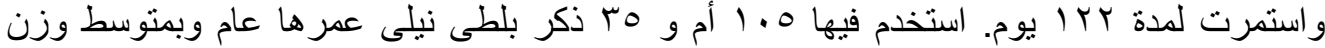

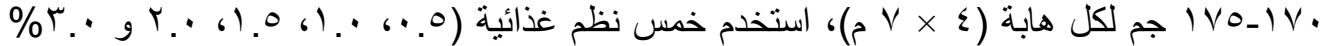

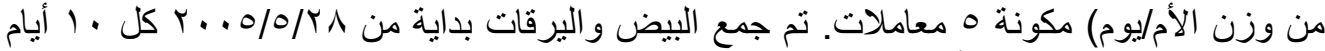

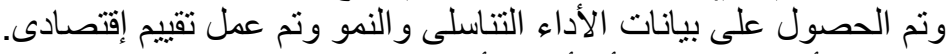

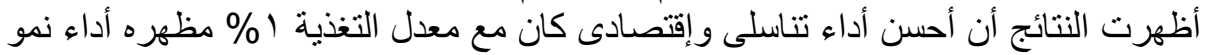

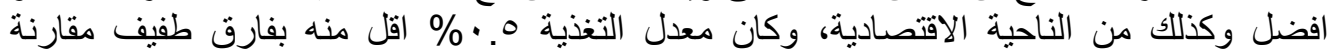
بمعدلات التغذية الأخرى العالية و التى لا يوصئ وكى بها. 